\section{(1) Melis Dülgeroğlu, (D) Nedim Çekmen}

\title{
Perioperative Care of Patients After Orthotopic Liver Transplantation
}

\author{
Ortotopik Karaciğer Transplantasyonu Hastalarında \\ Perioperatif Yönetim
}

Geliş Tarihi/Received : 10.09.2018

Kabul Tarihi/Accepted : 16.09.2019

()Telif Hakkı 2019 Türk Yoğun Bakım Derneği Türk Yoğun Bakım Dergisi, Galenos Yayınevi tarafından yayınlanmıştır.

Melis Dülgeroğlu, Nedim Çekmen

Güven Hastanesi, Anesteziyoloji ve Reanimasyon

Kliniği, Ankara, Türkiye

Dr. Melis Dülgeroğlu (凶),

Güven Hastanesi, Anesteziyoloji ve Reanimasyon Kliniği, Ankara, Türkiye

E-posta : melisturker@yahoo.com

Tel. : : : +905333282864

ORCID ID : orcid.org/0000-0001-7513-6007
ÖZ Günümüzde ortotopik karaciğer transplantasyonu (OKT) karaciğer yetmezliği hastalarında en kesin tedavi şeklidir. OKT sonrası postoperatif erken dönemde hemodinaminin stabilleşmesi, mekanik ventilasyon desteği ve doğru weaning ile oksijenizasyonun sağlanması, renal fonksiyonların korunması, hemostazın sağlanması temel hedeflerimiz olmalıdır. Tecrübeli bir yoğun bakım ekibi ile gelişebilecek komplikasyonların erken tanı ve tedavisi greft fonksiyonları ve sağkalım açııından önemlidir. Bu derlemede güncel literatür doğrultusunda OKT hastalarında perioperatif yoğun bakım yönetiminden bahsedildi.

Anahtar Kelimeler: Ortotopik karaciğer trnsplantasyonu, postoperatif yoğun bakım, postoperatif komplikasyonlar

\begin{abstract}
Nowadays, orthotopic liver transplantation (OLT) is the most definitive treatment in patients with end stage liver failure. In the early postoperative period after OCT, hemodynamic stabilization, maintenance of oxygenation with mechanical ventilation and weaning, preservation of renal functions and providing hemostasis should be our main targets. Early diagnosis and treatment of complications with an experienced intensive care team is important for graft function and survival. In this review, perioperative intensive care management of OLT patients was discussed according to current literature.
\end{abstract}

Keywords: Orthotopic liver transplantation, postoperative intensive care, postoperative complications

\section{Giriș}

Ortotopik karaciğer transplantasyonu (OKT) akut karaciğer yetmezliği, viral hepatitler, alkolik siroz, karaciğer maligniteleri ve pek çok metabolik hastalığın kesin tedavi yöntemidir (1,2). Illk kez 1963 yılında gerçekleştirilmiş olup günümüzde perioperatif ve postoperatif yoğun bakım yönetimindeki gelişmeler ile sağkalımda yüksek oranda artış sağlanmıştır $(3,4)$. Deneyimli yoğun bakım ekipleri tarafından gerçekleştirilecek etkili yoğun bakım yönetimi ile greft fonksiyonlarında artış, morbidite ve mortalitede azalma sağlanabilir. Hemodinamik stabilizasyon, mekanik ventilasyon, başarıı weaning, gelişebilecek komplikasyonların erken tanı ve tedavisi OKT sonrası erken dönem yoğun bakım yönetiminde önemli yer tutmaktadır.

\section{Preoperatif Değerlendirme}

Hastaların preoperatif değerlendirilmesinde karaciğer yetmezliği etiyolojisinin ve derecesinin belirlenmesi, diğer sistemler üzerine etkilerinin araştırılması ve eşlik eden komorbid durumların tanımlanması önemlidir (Şekil 1) $(5,6)$. Kronik karaciğer yetmezliği olan hastaların ChildPugh sınıflaması, Model for Endstage Liver Disease (MELD) skorlaması, King's College kriterleri kullanılarak hastaların aciliyet durumları ve cerrahi sonrası prognozları tanımlanabilir (Tablo 1, 2) (7,8). Acute Liver Failure Early Dynamic model ise erken dönemdeki değişkenleri kullanarak hastaların prognozu hakkında bilgi veren bir diğer skorlama yöntemidir (Tablo 3) (9). Alıcıya ait çoklu komorbid durumlar, Acute Physiology and Chronic Health Evaluation ve MELD skorlarının yüksek oluşu, acil nakil ihtiyacı, uzamış cerrahi ve klemp süreleri, transfüzyon intiyacı, preoperatif yoğun bakım ve entübasyon intiyacı olması gibi risk faktörlerinin varlığı erken dönem postoperatif komplikasyonlarda artışa neden olur (1,10-12). Transplantasyon kararı alınan hastaların kardiyovasküler, pulmoner, renal, gastrointestinal, hematolojik, metabolik ve nörolojik olarak değerlendirilmeleri, ileri tetkik ve tanıya yönelik 




Şekil 1. Akut karaciğer yetmezliğinin klinik özellikleri (6)

GIS: Gastrointestinal sistem, RAAS: Reninanjiyotensinaldosteron sistemi, KAH: Koroner arter hastalı̆ı̆, ARDS: Akut solunumsal distres sendromu

\begin{tabular}{|l|l|l|l|}
\hline \multicolumn{4}{|l|}{ Tablo 1. Child-Pugh sınıflaması } \\
\hline & 1 & 2 & 3 \\
\hline Asit & Yok & Orta derece & Masif \\
\hline Bilirubin (mg/dL) & $<2,0$ & $2,0-3,0$ & $>3,0$ \\
\hline Albümin (g/dL) & $>3,5$ & $2,8-3,5$ & $<2,8$ \\
\hline PTZ (sn) & $<4 ., 0$ & $4,0-6,0$ & $>6,0$ \\
\hline INR & $<1,7$ & $1,7-2,2$ & $>2,2$ \\
\hline Ensefalopati & Yok & Evre 1-2 & $\begin{array}{l}\text { Evre 3-4 } \\
\text { (dirençli) }\end{array}$ \\
\hline & Puan & $\begin{array}{l}\text { Bir yıllık } \\
\text { sağkalım }\end{array}$ & $\begin{array}{l}\text { İki yıllık } \\
\text { sağkalım }\end{array}$ \\
\hline Child A & $5-6$ & $\% 100$ & $\% 85$ \\
\hline Child B & $7-9$ & $\% 81$ & $\% 57$ \\
\hline Child C & $10-15$ & $\% 45$ & $\% 35$ \\
\hline PTZ: Protorombin zamanı, INR: International normalized ratio \\
\hline
\end{tabular}

\begin{tabular}{|l|l|}
\hline \multicolumn{2}{|l|}{ Tablo 2. MELD skorlaması } \\
\hline $\begin{array}{l}\text { MELD }=3,8 * \log _{\mathrm{e}}[\text { serum bilirubin }(\mathrm{mg} / \\
\left.\mathrm{dL})]+11,2 * \log _{\mathrm{e}}(\mathrm{INR})+9,6 * \log _{\mathrm{e}} \text { e [serum kreatinin }(\mathrm{mg} / \mathrm{dL})\right]+6,4\end{array}$ \\
\hline MELD skoru & Mortalite $(\%)$ \\
\hline$<9$ & 2 \\
\hline $10-19$ & 5 \\
\hline $20-29$ & 20 \\
\hline $30-39$ & 50 \\
\hline$\geq 40$ & 70 \\
\hline
\end{tabular}

testlerin planlanması perioperatif komplikasyonların gelişiminin önlenmesi ve yönetiminde önemli yer tutar (Şekil 2) (13).

\section{Kardiyovasküler Sistem}

OKT hastalarında postoperatif mortalitenin (\% 7-21) en sık üçüncü nedeni kardiyovasküler komplikasyonlardır $(14,15)$. Sirotik kardiyomiyopati (KMP) ve hiperdinamik dolaşım (HD) en sık karşılaşılan kardiyovasküler komplikasyonlardır.

Sirotik KMP strese karşı inotropik ve kronotropik cevapta yanıtsızlık, sistolik ve diyastolik disfonksiyon ve elektrofizyolojik anormallikler ile karakterizedir (Tablo 4) (1517).

Sirotik KMP'nin patofizyolojisinden sorumlu mekanizmalar (16);

- Nitrik oksit (NO) ve endokanabinoidlere bağlı HD ve negatif kronotropi,

- Vazodilatör bir ajan olarak bilinen karbonmonoksite bağlı negatif inotropik etki,

- $\beta 1 / \beta 2$ reseptörlerdeki down regülasyon,

- $\beta 3$ reseptörlerde katekolaminlere karşı negatif inotropik etki,

- Kalp kası hücrelerinin membranları arasındaki geçirgenliğin bozulması sonucu anormal biyokimyasal ve biyofiziksel fonksiyondur.

\begin{tabular}{|l|l|}
\hline Tablo 3. ALFED modeli \\
\hline 3 günlük değişkenler & Skor \\
\hline HE, geçici veya evre $>2$ & 2 \\
\hline INR, geçici veya $\geq 5$ & 1 \\
\hline Arter amonyak düzeyi, geçici veya $\geq 123 \mu \mathrm{mol} / \mathrm{L}$ & 2 \\
\hline Serum bilirubin geçici veya $\geq 15 \mathrm{mg} / \mathrm{dL}$ & 1 \\
\hline HE: Hepatik ensefalopati, INR: International normalized ratio \\
\hline
\end{tabular}

Preoperatif Değerlendirme

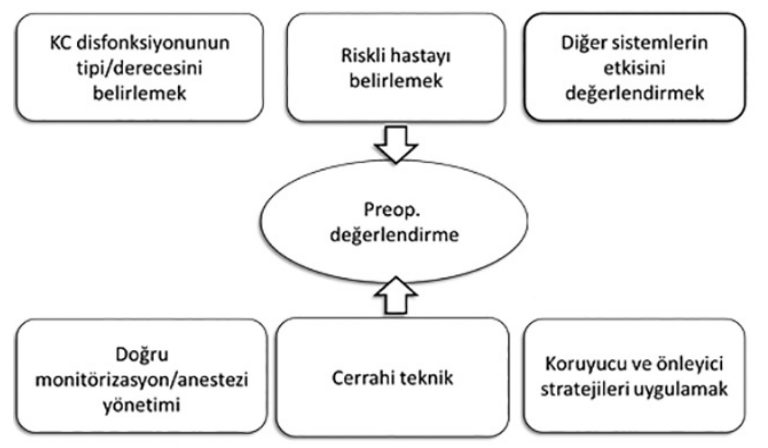

Şekil 2. Preoperatif değerlendirme (13)

KC: Karaciğer 
Siroz hastalarında bir diğer kardiyovasküler sorun HD'dir. Kalp hızı, kalp debisi ve sistemik vasküler dirençte (SVD) artış ve arteriyel kan basıncında azalma ile karakterizedir (18-20). Arteriyel splanknik vazodilatasyon pulmoner hipertansiyon (PH) ve HD oluşumundan sorumlu temel mekanizmalardan biridir. NO siroz hastalarında sistemik ve splanknik dolaşımdaki bilinen en potent vazodilatör ajandır. Intrahepatik dolaşımda NO azalır ve vazokonstrüksiyon (endotelin, anjiyotensin-2) etki oluşur. Endotel disfonksiyonuna bağlı siklooksijenaz1 ürünü olan prostanoidlerin oluşumu ile intrahepatik vasküler direnç artar; PH ve portosistemik şant oluşur. Dolaşımda NO başta olmak üzere araşidonik asit metabolitleri, kalsitonin gen ilişkili peptit ve diğer vazodilatör ajanlar $\operatorname{artar}(16,20)$. Sonuç etki olarak SVD azalır; bu azalma erken dönemde kalp debisi ve kalp hızındaki artış ile karşılanır (19). Sentetik vazopressin analoğu olan terlipressin, splanknik alanda vazokonstrüksiyon yapar ve bu alandaki arteriyel kan volümünü etkin bir şekilde değiştirir. lleri evre siroz hastalarında HD kompanzasyonda yetersiz kalır. Santral arteriyel kan volümünde (beyin, böbrek, kalp, akciğerler) meydana gelen azalma ile sempatik sinir sistemi, reninanjiyotensinaldosteron sistemi (RAAS) ve vazopressin salınımı aktive olur (Şekil 3) (19). HD arteriyel

\begin{tabular}{|l|}
\hline Tablo 4. Sirotik kardiyomiyopati tanımı ve tanımlama kriterleri \\
(12,17) \\
\hline Patofizyolojik nedenler \\
Strese karşı bozulmuş sistolik kasılma yanıtı \\
Dinlenim anında diyastolik disfonksiyon \\
Kardiyopulmoner hastalık bulgusu olmaması \\
\hline Sistolik disfonksiyon \\
Dinlenimde EF <\%55 \\
Egzersiz, volüm yükleme, farmakolojik uyarıma yanıtsızlık \\
\hline Diyastolik disfonksiyon \\
Erken/geç diyastolik dolum velosite oranı <1,0 \\
Uzamış mitral gevşeme zamanı (>200 ms) \\
İzovolümetrik gevşeme zamanında uzama (>80 ms) \\
\hline Destekleyici kriterler \\
Elektrofizyolojik bozukluklar \\
- Strese karşı bozulmuş kasılma yanıtı \\
- Elektromekanik senkronizasyon bozukluğu \\
- Uzamış QTc süresi \\
Kalp boşluklarında değişiklikler \\
pro-BNP ve BNP artışı \\
Troponin-1 artışı \\
\hline BNP: Beyin natriüretik peptit, EF: Ejeksiyon fraksiyonu \\
\hline
\end{tabular}

hipotansiyon, geniş nabız basıncı, taşikardi, ekstremitelerde sıcaklık artışı, palmar eritem ile kliniğe yansır (19).

Transplantasyon öncesi hastaların detaylı kardiyak öykülerinin alınması, fizik muayenelerinin yapılması ve gerekirse ileri kardiyak analiz ile kardiyak durumlarının değerlendirilmesi, etkili perioperatif hasta yönetimi sağlayarak sağkalımı olumlu etkiler (Şekil 4). Hastaların tümü preoperatif transtorasik ekokardiyografi (TTE) ile değerlendirilmelidir. Kardiyak risk faktörleri olan [iskemi, ileri kalp hastalığı, atriyel fibrilasyon (AF) vb.] hastalara transözefageal ekokardiyografi (TÖE) yapılmalıdır. Kardiyak risk faktörleri [diyabet, hipertansiyon, >50 yaş, hiperkolesterolemi, periferik damar hastalığı non-alkolik steatohepatitis, vb.] olduğu bilinen hastaların stres test (egzersiz, dobutamin) ile değerlendirilmesi gerekir. Dobutamin stres testi uygunsuz

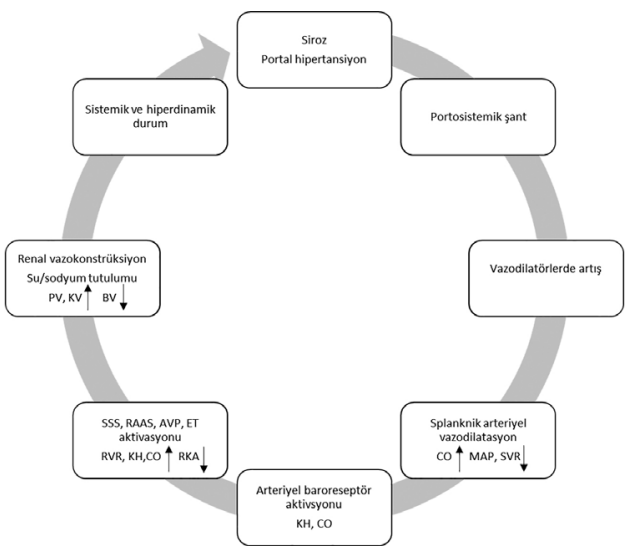

Şekil 3. Hiperdinamik sirkülasyon (19)

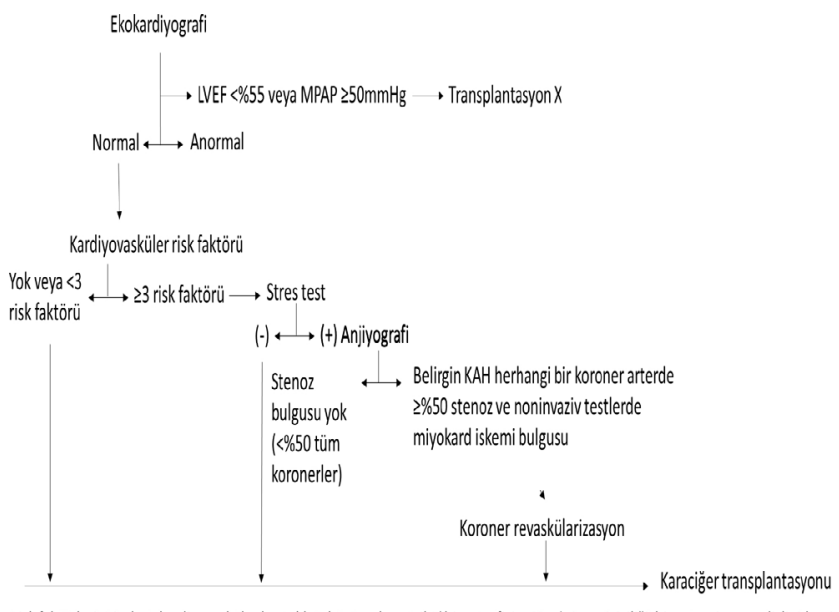

Risk faktörleri: Diyabet, kardiyovasküler hastalliköyküsü, sol ventrikül hipertrofisi, $>60$ yll sigara içciclig̈i, hipertansiyon ve dislipidemi

Şekil 4. Preoperatif ortotopik karaciğer transplantasyonu hastalarında kardiyak değerlendirme algoritması (15)

KAH: Koroner arter hastalı̆ı 
miyokard oksijen sunumunu ve koroner arter hastalığı (KAH) varlığını belirlemede başarılı bir görüntüleme yöntemidir. Anormal stres test bulguları olan hastalara ileri tetkik amacı ile koroner anjiyografi yapılmalıdır (8).

\section{Pulmoner Sistem}

Siroz hastalarında eşlik eden pulmoner sistem patolojileri sık görülür. Preoperatif pulmoner patoloji mortalite ve morbiditeyi artırır. HD'nin pulmoner dolaşım üzerine etkileri karşımıza hepatopulmoner sendrom (HPS) ve portopulmoner hipertansiyon (POPH) olarak ortaya çıkabilir.

HPS (21):

- Intrapulmoner vazodilatasyon,

- Sistemik arteriyel oksijenizasyonda azalma,

- Alveolararteriyel oksijen gradiyentinde $\left(\mathrm{AaDO}_{2}\right)$ bozulma (parsiyel arteriyel oksijen basıncının $\mathrm{PaO}_{2}<80$ mmHg; $\mathrm{AaDO}_{2}$ $>15 \mathrm{mmHg}$, $>64$ yaş hastalarda $>20 \mathrm{mmHg}$ ) ile karakterizedir.

HPS görülme sıklığı \%8-24'tür (8). Hastalarda ventilasyon/ perfüzyon bozukluğuna bağlı platipne, ortopne, ortodeoksi, spider nevi, dijital clubbing, siyanoz, ileri olgularda ise $\left(\mathrm{PaO}_{2}<60 \mathrm{mmHg}\right)$ hipoksemi görülür. Ortodeoksi, hastanın yatar pozisyondan dik oturur pozisyona geldiğinde veya ayağa kalktığında arteriyel oksijen basıncında $>4 \mathrm{mmHg}$ düşüş olması, arteriyel oksihemoglobin satürasyonunda $>\% 5$ düşüş olması ve bunların hasta yatar pozisyonda iken düzelmesidir. Ortodeoksi gelişmesi HPS gelişmiş olduğunu yüksek oranda destekleyen bir bulgudur (22). Akciğer grafisinde patolojik bulguya rastlanmazken intrapulmoner vazodilatasyonu saptamada en duyarlı tetkik kontrast ekokardiyografidir (19). HPS tedavisi transplantasyondur ve MELD skorundan bağımsız $\mathrm{PaO}_{2}<60 \mathrm{mmHg}$ olan hastalar acil transplantasyon adayıdırlar (19).

$\mathrm{POPH}$;

- Ortalama pulmoner arteriyel basınç (PAP) (>20 mmHg, $>30 \mathrm{mmHg}$ egzersiz ile),

- Pulmoner vasküler direnç artışı (240 dyne-sec. $\mathrm{cm}^{-5}$ ),

- Pulmoner arter kapanma basıncının $\leq 15$ mmHg olduğu durumdur.

Siroz hastalarında POPH görülme sıklığı \% 8-10'dur (19). Ortalama PAP $<35 \mathrm{mmHg}$ ise hafif $\mathrm{POPH}, 35-45 \mathrm{mmHg}$ ise orta $\mathrm{POPH},>45 \mathrm{mmHg}$ ise ağır/ciddi $\mathrm{POPH}$ olarak siniflandirilır (23). Semptomatik olan hastalar TTE ile değerlendirilmeli, sağ ventrikül sistolik basıncı yüksek saptanan hastalara sağ kalp kateterizasyonu yapılmalıdır (Şekil 4). Hafif POPH'de transplantasyon uygulanabilir. Orta POPH'de medikal tedavi ile PAH $<35 \mathrm{mmHg}$ hedef sağlanan hastalar transplantasyona uygundurlar. Ağır POPH'de ise transplantasyon uygulanmamalıdır (23). PAP yüksek olan hastalar TTE ile değerlendirilmelidir. Sağ ventrikül sistolik basıncın $>50 \mathrm{mmHg}$ olması durumunda kalp kateterizasyonu yapılarak $\mathrm{PH}^{\prime}$ ye neden olabilecek patolojiler dışlanmalıdır (8). POPH tedavisinde prostosiklin analogları, endotelin reseptör antagonistleri ve fosfodiesteraz-5 inhibitörleri kullanılmaktadır. POPH'nin en kesin tedavisi ise OKT'dir. Preoperatif farmakolojik yöntemler ile PAP $<35 \mathrm{mmHg}$ sağlanmasının postoperatif sağkalımı artırdığı bildirilmiştir $(24,25)$. Biz kliniğimizde bu hasta grubunda perioperatif dönemde milrinon ve magnezyum tedavilerini uyguluyoruz.

\section{Renal Sistem}

Hemodinamik ve metabolik değişikliklere bağlı siroz hastalarında \%18-40 sıklıkta hepatorenal sendrom (HRS) görülür (5). Splanknik alanda oluşan vazodilatasyon, santral hipovolemi, aktive olan RAAS'nin etkisiyle oluşan renal vazokonstrüksiyon ve nörohumoral mekanizmalar patofizyolojiden sorumludur (19). HRS'nin iki tipi tanımlanmıştır (Tablo 5).

HRS gelişen hastaların idrar çıkışları, sıvı dengeleri ve hemodinamik parametreleri yakın takip edilmelidir. Nonselektif beta blokör alan hastalarda renal kan akımının azalabileceği ve renal fonksiyonların kötüleşebileceği akılda tutulmalıdır. Birinci basamak tedavide terlipressin ve albümin uygulamasıdır. Bu tedavi yaklaşımında amaç SVD ve intravasküler volümü artırarak renal perfüzyonu sağlamaktır $(26,27)$. Preoperatif dönemde renal fonksiyonlar yakın takip edilmeli, diyaliz endikasyonu olan hastalar belirlenerek preoperatif diyaliz planları yapılarak cerrahiye verilmelidir.

\section{Gastrointestinal Sistem}

Siroz hastalarında oluşan portal basınç yüksekliği özofagusta varislere yol açar. Endoskopi ile varislerin tanısı, takibi ve kanama olması durumunda gerekli tedavinin yapılarak kanamanın durdurulması önemlidir. Kanaması olan hastalarda band-ligasyon veya betablokörler ile medikal tedavi uygulanabilir. HD ve karaciğerin sentez fonksiyonundaki yetersizlik nedeni ile başta albümin olmak üzere proteinlerde azalma sonucu onkotik basınç azalır, asit birikimi meydan gelir. Asit sirotik hastalarda \%60 sıklıkta görülür ve perioperatif mortaliteyi artıır (28). Tedavisinde diüretikler,

\begin{tabular}{|l|l|}
\hline \multicolumn{2}{|l|}{ Tablo 5. Hepatorenal sendrom } \\
\hline Tip 1 HRS & Tip 2 HRS \\
\hline Akut, ilerleyici, & Sessiz, yavaş ilerleyen \\
\hline $\begin{array}{l}\text { Serum kreatinin düzeyi } \\
>2,5 \mathrm{mg} / \mathrm{dL}\end{array}$ & Serum kreatinine $1,5-2,5 \mathrm{mg} / \mathrm{dL}$ \\
\hline HRS: Hepatorenal sendrom & \\
\hline
\end{tabular}


düşük sodyum ve sıvı içerikli diyet, albümin replasmanı, parasentez uygulanır. Asiti olan hastalarda spontan bakteriyel peritonit (SBP) ve HRS ile sık karşılaşılır. SBP abdominal ağrı, bulantı, kusma, ishal, hepatik ensefalopti, renal yetmezlik gibi klinik bulgu verir. Erken tanı ve antibiyotik tedavisi ile kontrol edilebilmesine rağmen bir kez SBP gelişimi tekrarlayan ataklar için risk faktörüdür ve sağkalımı olumsuz etkilemektedir (19).

\section{Hematolojik Sistem}

Koagülasyon ilişkili proteinlerin çoğu (prokagülan ve antikoagülan, fibrinolitik ve antifibrinolitik faktörler ile trombopoetin) karaciğerde sentezlenir. Siroz hastalarınsa hemostaz ilişkili faktör sentezlerindeki etkilenme sonucu kanama ve koagülasyon bozukluğu ortaya çıkar. Vitamin $\mathrm{K}$ bağımlı faktörler ( $F 2,7,9,10)$, faktör 5 , protein $C$, protein $S$, antitrombin, plaminojen, ADAMTS13 düzeyindeki azalma; doku faktörü, faktör-8, VonWillebrand faktör (VWF), doku plazminojen aktivatör, plazminojen aktivatör inhibitör1 düzeyinde ise artış görülür. Ek olarak disfibrinojenemi, platelet disfonksiyonu ve retiküloendotelyal sistem disfonksiyonu eşlik eder (Tablo 6) $(29,30)$. Bu sistemler arasındaki denge kanama ve tromboz riskini belirlerken, tromboza eğilim ile daha sık karşılaşıır. Preoperatif değerlendirmede protrombin zamanı, aktif protrombin zamanı, platelet sayısı, kanama zamanı, protein $\mathrm{C}$, protein $\mathrm{S}$ ve fibrinojen ölçümleri yapılmalıdır. Kanaması olan veya girişimsel işlem yapılması planlanan hastalarda bu kanama değerlerinin düzeltilmesi gerekir. Vitamin K ve ilişkili koagülasyon faktörlerinin eksikliği akılda tutulmalı ve preoperatif dönemde uygun şekilde replasmanı yapılmalıdır.

\section{Intraoperatif Hasta Yönetimi}

Karaciğer transplantasyon cerrahisinde tecrübeli bir cerrahi ekip ve anestezi takım çalışması oldukça önemlidir.
Anestezi yönetiminin, anestezistin tecrübesinin, hasta yönetiminde belirli standardizasyonlar oluşturmasının mortalite üzerine olumlu etkileri olduğu yapılan çalışmalarda bildirilmiştir $(31,32)$.

Hemodinamik monitorizasyon, ventilasyon/perfüzyonun sağlanması, koagülasyonun monitorizasyonu, sıvı elektrolit ve kan ürünü replasmanları, intraoperatif gelişen komplikasyonların yönetimi perioperatif takipte önemli yer tutar. Cerrahi süresince preanhepatik faz, anhepatik faz, iskemi/reperfüzyon fazlarında meydana gelen metabolik ve hemodinamik değişikliklerin yakın takibi ve anlık yönetilmesi gerekir. Hemodinamik monitorizasyon güvenli ve başarılı bir transplantasyonun olmazsa olmaz parçasıdır. Perioperatif dönemde hastalara ait fizyolojik parametrelerin yakın takibini, oluşan komplikasyonların erken saptanmasını, uygulanan tedavilere verilen yanıtının gözlemlenmesini, organ ve doku perfüzyonu hakkında bilgi edinilmesini, oksijenizasyonun değerlendirilmesini ve organ disfonksiyonlarının saptanmasını sağlar.

Standart monitorizasyona [elektrokardiyografi (EKG), pulse oksimetre, non-invaziv kan basıncı monitorizasyonu, kapnografi $\left(\Delta \mathrm{CO}_{2}\right)$, idrar çıkışı ve vücut sıcaklığı takibi] ek olarak invaziv monitorizasyon yöntemleri kullanılmalıdır. Invaziv arter basıncı, santral venöz basınç (CVP), santral venöz oksijen satürasyonu, kardiyak output (CO) monitorizasyonu ve pulmoner arter kataterizasyonlarının uygulanması önemlidir. CO, mikst venöz oksijen satürasyonu, sol ventrikül diyastol sonu (LVEDV) basınç değerlendirilmesinde altın standart pulmoner arter monitorizasyonudur (PAK). Öte yandan uygulamadaki zorluklar ve maliyet göz önünde bulundurulduğunda risk grubu hastalar belirlenerek PAK uygulaması önerilir (8). Intraoperatif TÖE uygulaması kardiyak patolojilerin ve hemodinamik instabiliteye yol açan nedenlerin saptanmasında önemlidir (31).

\begin{tabular}{|l|l|l|}
\hline \multicolumn{2}{|l|}{ Tablo 6. Karaciğer yetmezliğinde hemostaz parametreleri } \\
\hline Hemostaz & Tanısal testler & Prohemostaz \\
\hline Primer hemostaz & $\begin{array}{l}\text { Trombosit sayısı } \\
\text { Kanama zamanı } \\
\text { Trombosit fonksiyon analizatörü } \\
\text { TEM/TEG }\end{array}$ & $\begin{array}{l}\text { vWF artış } \\
\text { ADAMTS13 azalma }\end{array}$ \\
\hline Sekonder hemostaz & $\begin{array}{l}\text { PT ve aPTT } \\
\text { Trombin jenerasyonu } \\
\text { TEM }\end{array}$ & $\begin{array}{l}\text { Faktör 8 artış } \\
\text { AT3, protein C, S, alfa2 makroglobulin, heparin azalma }\end{array}$ \\
\hline Fibrinolizis & $\begin{array}{l}\text { Fibrinolizis belirteçleri } \\
\text { Euglobulin pıhtı lizis zamanı }\end{array}$ & PAi artış \\
\hline $\begin{array}{l}\text { TEM: Tromboelastometri, TEG: Tromboelastogram, vWF: Von-Willebrand faktör, PT: Protrombin zamanı, aPTT: Aktif protrombin zamanı, AT-3: Antitrombin, PAi: Plazminojen } \\
\text { aktivatör inhibitörü }\end{array}$ &
\end{tabular}


Intraoperatif hemodinamide meydana gelen değişiklikler kötü sağkalım ile ilişkilidir (33). Cerrahi sırasında vena kavaya klemp uygulaması, klemp süresi, ani kan ve sıvı kayıpları, iskemireperfüzyon hasarı, kalp yetmezliği, aritmiler, metabolik asidoz, elektrolit bozuklukları ve emboli gibi mekanik komplikasyonlar intraoperatif mortaliteyi artırır (5). Cerrahinin her üç fazında kanamaya bağlı ciddi sıvı kayıpları gözlenebilir. Kan kaybının önlenmesi için vena portanın klemplenmesi, venövenöz baypas uygulanması ve yıkamalı ototransfüzyon (cell saver) kullanılabilir. Intraoperatif ultrasonografi uygulanması ile reperfüzyon sonrası greft kanlanmasının ve safra yollarının değerlendirilmesi erken dönemde görülebilecek komplikasyonları önlemek açısından önemlidir.

Greft reperfüzyonunu takiben hastaların \%12-17'sinde postreperfüzyon sendromu gelişebilir. Sistolik kan basıncı ve CO'da azalma ile karakterizedir. Perioperatif bir yıllık mortalite ve renal disfonksiyon gelişiminde prediktör bir faktördür $(34,35)$. Postreperfüzyon sendromu akut gelişen ve hastaların \% 1 'inde intraoperatif kardiyak arrest gelişimine yol açabilir. Intraoperatif reperfüzyon öncesi uygulanan magnezyum infüzyonu iskemi/reperfüzyon süresini kısaltarak postoperatif kardiyak arrest riskini azaltır. Kardiyak arrest olan hastalara kardiyopulmoner resüsitasyon uygulanırken bir yandan antikoagülan tedavi uygulanması ve gerekirse kardiyopulmoner baypas ile desteklenmeleri gerekir (36).

Intraoperatif gelişebilen bir diğer komplikasyon vazoplejidir. Son dönem karaciğer hastalarında vasopressin yetmezliğinin neden olduğu intraopertatif ve postoperatif oluşabilen, hızlı tanınması ve tedavi edilmesi gereken bir klinik tablodur. Vasküler düz kas hücrelerinde G-protein aracılı reseptörlerde duyarsızlaşma, ikincil mesajcı sistemlerdeki değişiklikler, kritik hastalık ilişkili adrenokortikal yetmezlik ve NO yapımında artış gibi pek çok mekanizma vazopleji patofizyolojisinde rol oynar (Şekil 3) (37). Tedavide septik şokta görülen vazoplejilerde noradrenalin birinci basamak tedavi iken kardiyak cerrahi sonrası ve OKT ilişkili vazoplejilerde ilk basamak tedavide vazopressin uygulanmasının klinik sonuçları olumlu etkilediği yapılan çalışmalarda gösterilmiştir $(38,39)$. OKT'de görülen reperfüzyon sonrası vazoplejilerde katekolaminlere ve vazopressine direnç gözlenebilir. Katekolaminlere ve vazopressine direnç görülen hastalarda metilen mavisi kurtarıcı tedavi olarak akılda tutulmalıdır (Şekil 2) (40).

Hipotermi intraoperatif dönemde sık karşılaşılan erken müdahele edilmesi gereken ciddi sonuçları olan bir komplikasyondur. Hemodinamik instabilite, artmış SVD, bradikardi, oksijen tüketiminde artış, miyokardiyal iskemi, hiperviskozite, ventriküler aritmi hipotermi riskini arttırır. Hipotermi gelişimi kanamaya eğilim yaratır, hipoperfüzyona ve anaerobik metabolizmaya sonucu laktik asidoz birikmesine ve metabolik asidoz oluşumuna yol açar. Bu nedenle intraoperatif yakın Isı takibi yapılmalıdır. Eksternal ısıtma yöntemleri kullanıımalı, verilen sıvı ve kan ürünleri ısıtılarak verilmeli, ameliyat odasının sıcaklığı önemsenmelidir.

Intraoperatif dönemde cerrahinin tüm fazlarında meydana gelen sıvı elektrolit değişiklikleri farklıdır (Tablo 7). Oluşan

\begin{tabular}{|c|c|c|}
\hline Cerrahi faz & Metabolik bozukluklar & Elektrolit bozuklukları \\
\hline Diseksiyon fazı & $\begin{array}{l}\text { Hemoraji } \\
\text { Asit dekompresyonu } \\
\text { Hemodinamik instabilite } \\
\text { Hipotermi }\end{array}$ & $\begin{array}{l}\text { Hiponatremi } \\
\text { Hipokalsemi } \\
\text { Hipokalemi } \\
\text { Hipomagnezemi }\end{array}$ \\
\hline Anhepatik faz & $\begin{array}{l}\text { Hemoraji } \\
\text { Hemodinamik instabilite } \\
\text { Sitrat/laktat, glikoz metabolizması bozuklukları } \\
\text { Hipotermi }\end{array}$ & $\begin{array}{l}\text { Hipokalsemi } \\
\text { Hipomagnezemi } \\
\text { Hipofosfatemi }\end{array}$ \\
\hline Reperfüzyon fazı & $\begin{array}{l}\text { Hipoperfüzyon } \\
\text { Hipotansiyon } \\
\text { Bradikardi } \\
\text { SVD düşüklüğü } \\
\text { Hipotermi }\end{array}$ & $\begin{array}{l}\text { Hiperpotasemi } \\
\text { Hipomagnezemi } \\
\text { Laktat yüksekliği } \\
\text { Metabolik asidoz } \\
\text { Hipokalsemi }\end{array}$ \\
\hline
\end{tabular}


bozuklukların yakın takip edilerek uygun şekilde tedavi edilmesi gerekir.

Akut karaciğer yetmezliğindeki hastaların intrakraniyal basınç monitorizasyonu ile kafa içi basınçlarının ölçümü önerilir. Kafa içi basıncı yüksek, hepatik ensefalopatisi olan hastalarda mannitol diürezi, hipertonik salin uygulanması, barbitürat infüzyonu ile derin sedasyon, hipotermi uygulanması ile intraoperatif serebral ödemin önlenmesi ve kafa içi basıncının dengede tutulmasını sağlanır (8).

Siroz hastalarında perioperatif dönemde koagülasyonun değerlendirilmesi kanama ya da tromboza eğilimin saptanması hasta yönetimi açısından önemli olmakla birlikte bu konuda standart bir test yoktur. Tromboelastogram ve tromboelastometri koagülasyon ile ilgili değerli bilgi sağlamaktadır.

Hemodinaminin korunması, intravasküler efektif volümün, kardiyak debinin, doku perfüzyonunun, yeterli oksijen sunumunun ve ventilasyonun sağlanması, metabolik bozuklukların tanı ve tedavisi, bireysel yaklaşımla doğru anestezi yönetimi intraoperatif dönemde temel amaçlar olmalıdır.

\section{Postoperatif Yoğun Bakım Yönetimi ve Komplikasyonlar}

Günümüzde OKT sonrası hastaların yoğun bakımda takibi oldukça yaygındır $(8,12)$. Deneyimli bir yoğun bakım ekibi tarafından gerçekleştirilecek multidisipliner hasta yönetimi ile greft fonksiyonlarında iyileşme, postoperatif komplikasyonlarda azalma sağlanır. Hemodinamik stabilizasyon, mekanik ventilasyon ve weaning uygulanması, asidoz, hipotermi, koagülopati, elektrolit bozukluklarının takip ve tedavisi, renal fonksiyon takibi, uygun sıvı yönetiminin sağlanması, enfeksiyon profilaksisi, greft rejeksiyonunun önlenmesi, immünosüpresif tedavi ve erken dönemde gelişebilecek mekanik komplikasyonların yönetimi yoğun bakım hasta takibindeki hedeflerdir (1).

\section{Kardiyovasküler Komplikasyonlar ve Hemodinami Yönetimi}

Kardiyovasküler komplikasyonların OKT sonrası ile \%70 sıklıkta geliştiği, önemli mortalite (\%7) ve morbidite nedeni olduğu bildirilmiştir $(41,42)$. Intraoperatif kardiyak olay yaşanması, kardiyak hastalık ve/veya hipertansiyon öyküsü olması ve yüksek MELD skoru transplantasyon sonrası ilk altı ayda karşılaşılan kardiyovasküler komplikasyonlar için bağımsız risk faktörleridir (43). Sirotik KMP, kronik sigara kullanımı, renal fonksiyon bozukluğu, ileri yaş diğer risk faktörleridir (14).
Transplantasyon sonrası greft fonksiyonlarının korunmasında, hastaların komorbid durumları göz önünde bulundurularak uygun hemodinaminin sağlanması önemlidir. Preoperatif bilinen $\mathrm{KAH}$, sirotik KMP gibi kardiyak risk faktörü olan hastaların yoğun bakım süreçlerinde EKG, invaziv arter monitorizasyonu, CVP'ye ek olarak transpulmoner termodilüsyon (PICCO, LIDCO) veya PAK ile ileri hemodinamik monitorizasyon uygulanması daha güvenilir ve doğru hemodinamik yönetim sağlar. Postoperatif dönemde hemodinamik yönetimde hedef, optimum greft ve uzak organ perfüzyonunu sağlayacak ortalama arter basıncı ve kardiyak dolum basınçlarının sağlanması olmalıdır (1).

Preoperatif dönemde görülen $\mathrm{HD}, \mathrm{KAH}$ ve kalp yetmezliği bulgularının baskılanmasına neden olabilir. Metabolik bozukluklar, asidoz, hipotermi, elektrolit bozuklukları, intraoperatif reperfüzyon sendromu gelişmesi postoperatif kardiyak performansı etkileyen faktörlerdir (1). Öte yandan OKT sonrası artan periferik vasküler direnç ve kan basıncı, kardiyak ön ve ard yükü artırmakta; bu artış özellikle preoperatif sirotik KMP'si olan hastalarda kalp yetmezliği bulgularına neden olabilmektedir (15). Yetmezlik gelişmesi kliniğe hipotansiyon, akciğer ödemi, uzamış mekanik ventilatör intiyacı ile yansır.

Postoperatif hipotansiyonun en önemli nedeni kanamadır. Kanamaların bir kısmı yeniden cerrahiye alınarak durdurulsa da çoğu diğer nedenlere bağlı olarak yoğun bakım koşullarında kontrol edilir. Kanama parametrelerinin takibi ile greft kan akımı göz önünde bulundurularak gerekli replasmanların (trombosit, taze donmuş plazma, tam kan, eritrosit süspansiyonu) yapılması önemlidir.

OKT sonrası akciğer ödemi \%12-56 sıklıkta gelişir $(1,44)$. Kardiyovasküler komplikasyon gelişen hastalarda ileri monitorizasyon yöntemleri ile sağ ve sol ventrikül ön ve ard yükü, ekstravasküler akciğer suyu, CO, LVEDV, SVD, pulmoner vasküler direnç, intratorasik kan volümü, global diyastol sonu volüm parametreleri ile hemodinami değerlendirilerek uygun sıvı replasmanı ve inotrop ilaç tedavisi uygulanması hedeflenebilir.

Postoperatif dönemde hastalarda hipotansiyon ile sık karşılaşılır. Hipovolemi, intraoperatif düşük CVP ile greft konjesyonunun önlenmeye çalışılması, vazodilatasyon, uzamış reperfüzyon sendromu, hipokalsemi, miyokard iskemisi, sol ventrikül disfonksiyonu hipotansiyon gelişimine neden olan faktörlerdir (12). Hipotansiyonun önlenmesinde uygun sIVI replasmanı oldukça önemlidir. Ortalama arter basıncı ve CO düşük olan hastalarda SVD'nin düşük saptanması durumunda 
inotrop ajanlar (noradrenalin, dopamin, dobutamin, adrenalin, terlipressin) tedaviye eklenmelidir.

Postoperatif AF OKT sonrası en sık karşılaşılan aritmidir (45). Elektrolit bozuklukları (hipomagnezemi, hipokalemi, hipokalsemi), hipoksemi, anemi, miyokard iskemisi, ajitasyon, preopreatif AF öyüsü, ileri yaş, vücut ağırlığı, MELD skoru AF gelişimi için risk faktörleri olarak bildirilmiştir $(12,15)$. AF gelişen hastalarda CO'daki azalmaya bağı hemodinamide bozulma meydana gelir. Bu nedenle öncelikle altta yatan nedenin düzeltilmesi, gerekirse medikal tedavi (beta blokörler, amiodoron, kalsiyum kanal blokörleri) veya kardiyoversiyon ile normal ritmin sağlanmaya çalışımalıdır.

Hastalarda görülen hipertansiyonun tedavisi de greft fonksiyonu açısından önemlidir. Postoperatif dönemde ajitasyon, anksiyete, ağrı, entübasyon, hipotermi, vazopressör uygulamalarına bağlı oluşabilen hipertansiyon altta yatan nedenler düzeltilmesine rağmen kontrol edilemezse medikal tedavi ile kontrol edilmelidir (12).

\section{Sıvı Elektrolit Yönetimi}

Intraoperatif dönemde her cerrahi fazda farklı sIVı ve elektrolit kayıplar oluşur. Hastalar yakın monitorize takip edilmeli, oluşan metabolik sorunların hızlı tanı ve tedavi edilmelidir (Tablo 8). Hipomagnezemi, hipofosfatemi, hiperkalemi, hipokalemi, hiponatremi, hipokalsemi ve hipoglisemi sık karşılaşılan elektrolit bozukluklarıdır. Hipomagnezemi önemli aritmi nedeni iken hipofosfatemide kas güçsüzlüğü, uzamış mekanik ventilasyon intiyacı, miyokard kasılmasında bozulmaya yol açar. HRS, akut böbrek hasarı $(A B H)$, uzamış reperfüzyon sendromu, perfüzyon sıvısı ve kan transfüzyonları ile ilişkili hiperkalemi gelişebilir. Kardiyak yan etkileri nedeni ile hiperkalemi tanısının hızla konulması ve tedavi edilmesi önemlidir. Medikal tedaviye yanıt alınamadığı durumlarda hiperkalemi tedavisi için diyaliz yöntemleri akılda bulundurulmalıdır. Transplantasyon sonrası normoglisemi greft fonksiyonunun normal olduğu ile ilgili önemli bir gösterge iken hipoglisemi kötü greft fonksiyonu ile direkt ilişkilidir (1). Hastalarda normoglisemi sağlanmalı <180 mg/dL kan şekeri düzeyi hedeflenmeli ayrıca sıkı kan şekeri regülasyonundan kaçınılmalıdır.

Intraoperatif ve postoperatif dönemde ideal SIVI ve kan replasmanı yapılması önemlidir. Masif kan transfüzyonu, yüksek miktarda sıvı volüm yükü postoperatif mortalite ile ilişkilidir. Masif sıvı replasmanı kardiyak yüklenme, sodyum retansiyonu, kapiller kaçış sendromuna bağı intravasküler volümün sağlanamaması sonucu ödem oluşumuna ve konjesyona neden olarak greft perfüzyonu bozar (1).
Hastaların ileri monitorizasyon yöntemleri uygulanarak (CO monitorizasyonu, TTE, PAK, vb.) değerlendirilmesi volüm durumları hakkında daha güvenilir veriler sağlar. Reydellet ve ark.'nın (46) çalışmasında 4-6 mL/kg/s kristaloid, düşük doz kolloid uygulanan protokol grubunda mekanik ventilasyon süresinin kısaldığı, postoperatif ileus sıklığının azaldığı ve sağkalımın daha iyi olduğunu bildirmiştir. Bir kolloid solüsyon olan albüminin onkotik basınç artırarak ve etkili intravasküler volüm sağlayarak sepsiste sağkalıma olumlu etkisi olduğu bilinmektedir. Albüminin \%4-5 ve \%20-25'lik solüsyonları sıvı replasmanında kullanılmaktadır. Yüzde yirmilik albümin solüsyonu daha düşük volümde uygulanarak

\begin{tabular}{|c|c|c|}
\hline & Nedenleri & Komplikasyonlar \\
\hline $\begin{array}{l}\text { Hiponatremi } \\
<125 \mathrm{mEq} / \mathrm{L}\end{array}$ & $\begin{array}{l}\text { Hipervolemi } \\
\text { Asit } \\
\text { HRS } \\
\text { Diüretikler }\end{array}$ & $\begin{array}{l}\text { Postop mortalite } \\
\text { ilişkili }\end{array}$ \\
\hline $\begin{array}{l}\text { Hipernatremi } \\
\text { >145 mEq/L }\end{array}$ & $\begin{array}{l}\text { Yetersiz sıvı } \\
\text { Aşırı sıvı kaybı } \\
\text { Masif transfüzyon } \\
\text { İyatrojenik }\end{array}$ & $\begin{array}{l}\text { Postop mortalite } \\
\text { ilişkili }\end{array}$ \\
\hline $\begin{array}{l}\text { Hiperpotasemi } \\
>5,5 \mathrm{mEq} / \mathrm{L}\end{array}$ & $\begin{array}{l}\text { Bazal yükseklik } \\
\text { Masif transfüzyon } \\
\text { Uzamış sıcak iskemi } \\
\text { Böbrek yetmezliği } \\
\text { İntraop oligüri } \\
\text { Prefüzyon solüsyonu } \\
\text { Metabolik asidoz }\end{array}$ & $\begin{array}{l}\text { Postop mortalite } \\
\text { ilişkili } \\
\text { Reperfüzyonda } \\
\text { kardiyak arrest }\end{array}$ \\
\hline $\begin{array}{l}\text { Hipopotasemi } \\
<3,5 \mathrm{mEq} / \mathrm{L}\end{array}$ & $\begin{array}{l}\text { Diüretik } \\
\text { Alkaloz } \\
\text { Aşırı diürez }\end{array}$ & \\
\hline $\begin{array}{l}\text { Hipokalsemi } \\
<8,5 \mathrm{mEq} / \mathrm{L}\end{array}$ & $\begin{array}{l}\text { Bazal düşüklük } \\
\text { Masif transfüzyon } \\
\text { (sitrat toksisitesi) } \\
\text { Böbrek yetmezliği } \\
\text { Diüretik }\end{array}$ & $\begin{array}{l}\text { Postop mortalite } \\
\text { ilişkili } \\
\text { Pıhtılaşma } \\
\text { bozuklukları } \\
\text { Negatif inotropik } \\
\text { etki } \\
\text { Vasküler tonusta } \\
\text { azalma }\end{array}$ \\
\hline $\begin{array}{l}\text { Hipomagnezemi } \\
<1,7 \mathrm{mEq} / \mathrm{L}\end{array}$ & $\begin{array}{l}\text { Bazal düşüklük } \\
\text { Masif transfüzyon } \\
\text { Diüretikler } \\
\text { Malnütrisyon }\end{array}$ & $\begin{array}{l}\text { Postop mortalite } \\
\text { ilişkili }\end{array}$ \\
\hline \multicolumn{3}{|c|}{ HRS: Hepatorenal sendrom } \\
\hline
\end{tabular}


\%4 albüminle aynı intravasküler volüm oluşturabilir. Buna rağmen hiperonkotik durum oluşturarak glomerüler filtrasyon hızında azalmaya ve aşırı intravasküler yüke neden olabilir. Bu nedenle \%4 albümin kullanımı klinikte daha güvenilir bulunmuştur (47).

\section{Pulmoner Bakım, Erken Solunumsal Komplikasyonlar ve Weaning}

Preoperatif dönemde hipoksemik olan hastalarda postoperatif pulmoner komplikasyon gelişme sıklığının \%4046 olduğu bildirilmiştir $(10,48)$. Postoperatif gelişen pulmoner komplikasyonlar mortalite ve morbidite ile direkt ilişkilidir. Preoperatif pulmoner sisteme patolojisi bulunması (POPH, HPS), diyabet, sigara kullanımı, yüksek MELD skoru, ileri yaş, preoperatif mekanik ventilatör ihtiyacl; intraoperatif olarak uzamış cerrahi süre, masif kan ve sıvı transfüzyonu, reperfüzyon sendromu, sağ diyafragma paralizisi; postoperatif dönemde ise immünosüpresif tedavi, $\mathrm{ABH}$ gelişimi, greft rejeksiyonu, mekanik komplikasyonlar postoperatif pulmoner komplikasyon gelişimi için risk faktörleridir. Plevral effüzyon, atelektazi, pulmoner ödem, akut solunumsal distres sendromu (ARDS) ve pnömoni sık karşılaşlan postoperatif pulmoner komplikasyonlardır $(10,12)$.

Siroz hastalarında POPH ve HPS'ye bağlı gelişen ventilasyon/perfüzyon uyumsuzluğu ve hipoksemi genellikle transplantasyon sonrası düzelir. Postoperatif akut gelişen hipoksemi, hipokarbi, solunum yetmezliği ve $\mathrm{PH}$ gelişiminde akut pulmoner emboli akılda tutulmalıdır.

Preoperatif dönemde hepatik hidrotoraksa bağlı sağ plevrada sıklıkla transüda nitelikte plevral efüzyon mevcuttur. Postoperatif dönemde efüzyon miktarında azalma beklenir; ancak efüzyon miktarında artış, sol plevrada efüzyon ve oksijenizasyonun bozulması durumunda altta yatan nedenler sorgulanmalıdır. Uzun dönemde atelektazi gelişimine ve pnömoni oluşumuna zemin hazırlaması nedeni ile efüzyon oluşumunda öncelikle altta yatan nedenler düzeltilmeli gerekirse boşaltıcı torasentez uygulanmalıdır.

Postoperatif pulmoner ödem radyolojik olarak saptanır; gaz değişimini etkilemez ve klinik bulgu vermez. $A B H$ ve yüksek miktarda sıvı replasmanı uygulanması, kalp yetmezliği bulunması durumunda masif pulmoner ödem gelişebilir (10). Preoperatif TTE ile postoperatif pulmoner ödem gelişimi açısında risk grubu hastalar belirlenebilir. Örneğin; preoperatif $\mathrm{PH}$ olan ve sağ ventrikül dolum basınçları yüksek olduğu bilinen bir hastada uygun sıvı replasmanı yapılması postoperatif pulmoner ödem gelişmesi açısından oldukça önemlidir. OKT sonrası akciğer dokusunda artan kan akışının yol açtığı alveollerde epitel hasara bağlı oluşan stres yanıt ile ikincil yolaklar uyarılır. Bu uyarı sonucu açığa salınan NO, prostoglandinler ve endotel ilişkili faktörlere bağlı pulmoner ödem gelişebilir $(49,50)$.

Erken postoperatif dönemde transfüzyon ilişkili akciğer hasarı (TRALI) veya ARDS gelişebilir. Postoperatif ARDS \%5-15 sıklıkta görülür ve \%80 mortal seyreder (51). Özellikle platelet transfüzyonu ile ilişkili akciğer hasarının yüksek postoperatif mortalite ilişkili olduğu bildirilmiştir (52). Plateletlerin endotelde agregasyonu, içerdikleri vazoaktif ve enflamatuvar mediatörler ve sitokinlerin salınımı alveollerde hasara yol açar. Uzamış ameliyat süresi, masif kanama, reperfüzyon sendromu, postoperatif erken dönemde görülen enfeksiyonlar ARDS gelişimindeki diğer risk faktörleridir. ARDS tedavisinde sIVI kısıtlaması, invaziv veya noninvaziv mekanik ventilasyon (NIMV) desteği ile normoksemi ve normokarbi sağlanması temel hedef olmalıdır.

Postoperatif pnömoni gelişme sıklığı \%5-38 iken pnömoni ilişkili mortalite \%40 olarak bildirilmiştir (10). Preoperatif dönemde akciğer hasarı olan hastalar risk grubunu oluşturur. Pnömoni görülme sıklığının postoperatif altıncı günde en yüksek olduğu bildirilmiştir (10). En sık gram negatif mikroorganizmalara bağlı oluşur. Postoperatif uzamış mekanik ventilasyon süresi başlıca risk faktörüdür. Pnömoninin erken tanısı, erken ampirik antibiyotik tedavisi ve sorumlu patojenin saptanarak uygun antibiyotik tedavisi ile devam edilmesi önemlidir.

Bazı transplantasyon merkezlerinde ameliyathane ortamında erken ekstübasyon uygulanmaktadır. Erken ekstübasyonun pulmoner komplikasyon gelişimini azalttı̆̆ı, greft fonksiyonlarını iyileştirdiği bilinmektedir. Ancak komorbid durumlar, cerrahi sırasında gelişen asidoz, hipotermi ve reperfüzyon sendromu, uzun cerrahi süre, uzamış kas gevşetici infüzyonuna bağlı solunum kas güçsüzlüğü, ağrı gibi risk faktörleri varlığında yoğun bakımda ekstübasyon daha güvenlidir. Başarısız ekstübasyon doku hipoksisine yol açarak greft fonksiyonlarını kötü etkileyebilir. Özellikle preoperatif ensefalopati, acil cerrahi, obezite, greft disfonksiyonu şüphesi, hipoksemi, pulmoner ödem, hemodinamik instabilite, inotrop ajan ihtiyacı olan hastalarda yoğun bakımda stabil koşullar sağlanarak weaning planları yapılmalıdır. ARDS, TRALI, uzamış reperfüzyon sendromu, non-fonksiyonel greft, greft rejeksiyonu, mekanik komplikasyonlar gelişmesi durumunda zorlu weaning ile karşılaşılabilir. Bu gibi durumlarda sedatif 
ajanlar ile hastaların ventilatör uyumu sağlanmalı, pozitif basınçlı ventilasyon uygulanmalı ve altta yatan nedenin kontrolü sağlanarak mümkün olan ek kısa sürede weaning planlanmalıdır. Ekstübasyon sonrası pozitif basınç intiyacı öngörülen hastaların belirlenerek NIMV uygulanması doku hipoksemisi önleyerek greft fonksiyonlarının korunmasını sağlar. Uygun greft fonksiyonu için güvenilir pozitif end ekspiratuvar basıncı (PEEP) belirlenmesi önemlidir. Bu konuda yapılan yapılan çalışmalarda, $15 \mathrm{mmHg}$ PEEP seviyelerinde hepatik ven, portal ven ve hepatik arter akımlarını korunduğu bildirilmiştir (53).

\section{Renal Komplikasyonlar}

ABH OLT sonrası hastalarda \%11-68 sıklıkta gelişmektedir ve önemli bir postoperatif motalite nedenidir $(1,12,54,55)$. ABH tanımlanmasında RIFLE, AKIN veya güncellenmiş haliyle KDIGO kriterleri kullanılmaktadır (Tablo 9). MELD skorunun yüksek oluşu ve non-alkolik yağlı karaciğer hastalığı postoperatif $\mathrm{ABH}$ gelişmesinde risk faktörüdür (55). Intraoperatif iskemireperfüzyon hasarı, reperfüzyon sendromu, hemodinamik instabilite ve kaval klemp kullanılması renal perfüzyonda bozulma sonucu ABH'ye neden olmaktadır. Soğuk/sıcak iskemi süreleri, greft disfonksiyonu ve OKT sonrası aspartat aminotransferaz yüksekliği postoperatif $\mathrm{ABH}$ ile ilişkili bulunmuştur (55). Intraoperatif ideal Sıvı replasmanını belirlemeye yönelik yapılan çalışmalarda normal salinin hiperkloremik metabolik asidoz gelişimi ile renal perfüzyonda bozulmaya ve $\mathrm{ABH}^{\prime}$ ye yol açtığı, hidroksietil starch (HES) kullanımının da direkt $\mathrm{ABH}$ ilişkili olduğu ve yüksek volümde sıvı replasmanının renal fonksiyonları olumsuz etkilediği bildirilmiştir (55-57). ABH'yi önlemeye yönelik ideal sıvı replasmanı planlanırken hastaya ait risk faktörleri belirlenmeli, ileri hemodinamik monitorizasyon yöntemler kullanılmalıdır.

Kreatinin düzeyi, saatlik idrar çıkışı $A B H$ takibinde klinikte yaygın kullanılan parametrelerdir. Yeni bir biyomarker nötrofil jelatinaz ilişkili lipokalinin (NGAL) idrarda artışının renal hasar ilişkili olduğu bildirilmiştir (58). Reperfüzyonun ilk 24 saatinde $A B H$ gelişimini göstermede tek ölçümde yüksek NGAL seviyesi saptanması, serum kreatinin düzeyindeki artıştan daha anlamlı bulunmuştur (58). Ek olarak renal hasar molekül-1, karaciğer yağ asit bağlayıcı protein ve interlökin-18 yapılan çalışmalarda renal tübüler hasarı ile ilişkili bulunmuşlardır (59).

Renal fonksiyonların korunmasına intraoperatif dönemde başlanır. Postoperatif gelişen $A B H$ sıklıkla intraoperatif

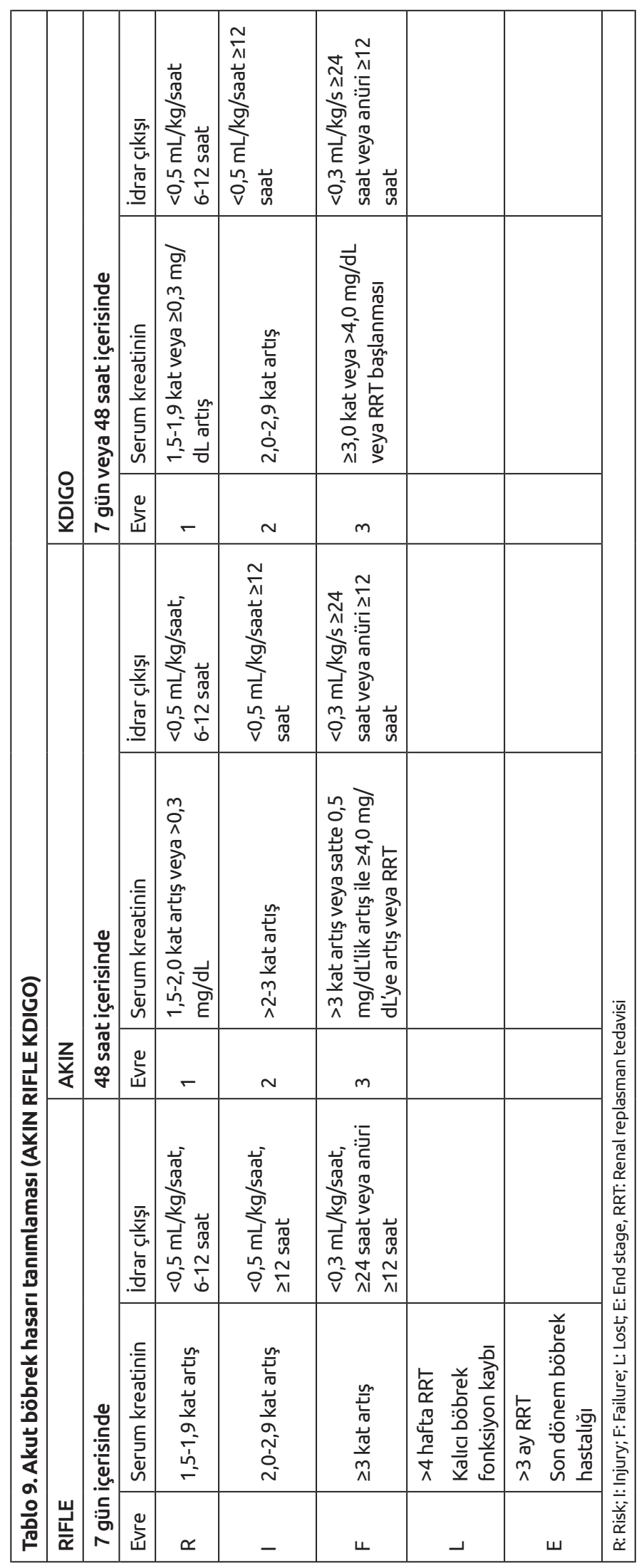


iskemireperfüzyon hasarı ve hemodinamik instabiliteye bağı gelişir (55). Hemodinaminin korunması, reperfüzyon fazında meydana gelen metabolik değişikliklerin düzeltilmesi, hipotansiyondan kaçınılması, gerektiğinde inotropik ajan başlanarak normatansif kalınması, uygun cerrahi teknik kullanılması önemlidir.

$\mathrm{ABH}$ gelişmesi durumunda intraoperatif ve postoperatif renal replasman tedavisi (RRT) uygulanabilir. Üremi, diüretiklere yanıtsız volüm yükü, hiperpotasemi, asidoz gelişiminde RRT endikasyonları iyi belirlenmeli ve uygulama kararı gecikmeden verilmelidir. Sürekli RRT (SRRT) hemodinamisi instabil, inotropik ajan infüzyonu alan, septik şoktaki hastalarda uygulanmaktadır. Yapılan bir meta-analizde aralıklı RRT ile SRRT karşılaştırılmış ve SRRT'nin böbrek fonksiyonlarını iyileştirmede daha etkili olduğu saptanmış (58). Yüksek maliyet devamlı antikoagülan infüzyon ihtiyacı ise SRRT uygulamasının dezavantajlarıdır.

\section{Gastrointestinal Sistem ve Beslenme}

Transplantasyona aday hastalar preoperatif dönemde sıklıkla malnütriyedirler. Malnütrisyon solunumsal ve enfeksiyöz komplikasyonlarda ve yoğun bakım kalış süresinde artışa neden olmaktadır (60). Bu nedenle hastaların postoperatif erken dönemde beslenmeleri önemlidir. Güncel beslenme rehberlerinde oral alamayan hastalarda bir haftaya kadar parenteral beslenme için beklenebileceği ancak bu karar verilirken hastaların malnütrisyon durumlarının iyi belirlenmesi gerektiği vurgulanmıştır. OKT hastaları da preoperatif kalori ve protein açığı olan ve postoperatif dönemde enerji intiyaçları olan hasta grubudur. Cerrahiye bağlı veya diğer nedenlerle enteral/oral beslenemeyen hastaların günlük kalori ve protein ihtiyaçlarının karşılanması amacı ile parenteral beslenme başlanabilir. Günlük elektrolit, vitamin, eser element desteklerinin de sağlanması da önemlidir.

Bulantı, kusma, gastrik pasajda yavaşlama, karın ağrısı, kabızlık, kanama, pankreatit ve anastomoz kaçağı postoperatif dönemde karşılaşılan gastrointestinal sistem soruları arasındadır. Komplikasyonların erken tanınması ve müdahelesi önemlidir.

\section{Nörolojik Komplikasyonlar}

Postoperatif nörolojik komplikasyonlar organ transplantasyonu sonrası sık karşılaşılan sorunlar arasındadır. Pek çok çalışmada nörolojik komplikasyonların yönetiminin postoperatif sağkalımı olumlu etkilediği gösterilmiştir. Canlı vericiden yapılan nakillerde nörolojik komplikasyonların kadavra vericiye oranla daha az olduğu bildirilmiştir. Nöbet, serebrovasküler komplikasyonlar, santral sinir sistemi (SSS) enfeksiyonları ve santral pontin miyelinizasyon postoperatif karşılaşılan nörolojik komplikasyonlardır. Preoperatif HES veya diğer nörolojik sistem bulgusu olan hastalar postoperatif kognitif disfonksiyon gelişimi açısından risklidir. Immünosüpresif tedaviler SSS'ye direkt nörotoksik etki gösterebilir. Sıklıkla kalsinörin inhibitörleri, kortikosteroidler, poliklonal ve monoklonal antikor tedavilerine bağlı ensefalopati gelişmektedir. Erken postoperatif dönemde kalsinörin inhibitörlerinin yüksek doz kullanımı, bozulmuş kan-beyin bariyeri ve intravenöz kullanıma bağlı nörotoksisite riski artar (61). Nörotoksisite tremor, baş ağrısı, ensefalopati ile kliniğe yansır.

Immünosüpresif tedaviye bağlı fırsatçı SSS enfeksiyonları menenjit, meningoensefalit veya fokal apse şeklinde oluşabilir. Profilaktik ilaç kullanımı ve teröpatik yaklaşımlardaki ilerlemeye rağmen fırsatçı SSS enfeksiyonları önemli oranda mortalite ve morbiditeye yol açmaktadır.

Nörolojk fonksiyonlarda bozulma olması greft disfonksiyonunun ilk bulgusu olarak karşımıza çıkabilir. Gecikmiş posterior lökoensefalopati ve santral pontin miyelinozis gibi daha ciddi komplikasyonlar nadir görülen SSS komplikasyonlarıdır.

\section{Greft Fonksiyon Takip ve Yönetimi}

Greft fonksiyonları reperfüzyonu takiben intraoperatif dönemde değerlendirilmeye başlanır postoperatif takip ile devam eder. Hemodinamik veriler, biyokimyasal değerler, kanama parametreleri, grefte ait görsel değerlendirme intraoperatif dönemde önemlidir. Hepatik arter/ven ve portal ven trombozu, hiperakut rejeksiyon, kanama, iskemi/ reperfüzyon hasarı postoperatif dönemde gelişen greft ilişkili komplikasyonlardır. Yoğun bakımda karaciğer kan akımlarının ve safra akışının Doppler ultrasonografi ile takibi, yakın hemodinamik monitorizasyon, biyokimyasal değerlendirme erken greft fonksiyon bozukluğunu saptamada önemlidir. Postoperatif karaciğer disfonksiyonunun erken tespitinde non invaziv bir değerlendirme testi olan LiMON sistemi önemli yer tutar. Indosiyanin yeşili kullanılarak plazmadan kaybolma hızına bakılarak (plasma disappearance rate of indocyanine green PDR-ICG) karaciğerin eliminasyon ve dolaşım özellikleri hakkında bilgi sağlar.

\section{Sonuç}

Karaciğer transplantasyonu son dönem karaciğer hastalığı tedavisinde en etkili tedavi yöntemidir. Bu dinamik 
prosedürde hastaların perioperatif multidisipliner yaklaşım ile değerlendirilerek yönetilmeleri oldukça önemlidir. Deneyimli yoğun bakım ekibi tarafından uygulanacak güvenilir ve etkili perioperatif yönetim ile greft fonksiyonlarında iyileşme, komplikasyonların önlenmesi, saptanması ve etkili şekilde tedavi edilmesi ile sağkalım oranlarında artış sağlanacaktır.

\section{Etik}

Hakem Değerlendirmesi: Editörler kurulu ve editörler kurulu dışında olan kişiler tarafından değerlendirilmiştir.

\section{Yazarlık Katkıları}

Cerrahi ve Medikal Uygulama: M.D., N.Ç., Konsept: M.D., N.Ç., Dizayn: M.D., N.Ç., Veri Toplama veya Işleme: M.D., Analiz veya Yorumlama: M.D., Literatür Arama: M.D., Yazan: M.D.

Çıkar Çatışması: Yazarlar bu makale ile ilgili olarak herhangi bir çıkar çatışması bildirmemiştir.

Finansal Destek: Çalışmamız için hiçbir kurum ya da kişiden finansal destek alınmamıştır. 


\section{Kaynaklar}

1. Feltracco P, Barbieri $S$, Galligioni $H$, Michieletto E, Carollo C, Ori C. Intensive care management of liver transplanted patients. World J Hepatol 2011;3:61-71.

2. Starzl TE, Marchioro TL, Vonkaulla KN, Hermann G, Brittain RS, Waddell WR. Homotransplantation of the Liver in Humans. Surg Gynecol Obstet 1963;117:659-76

3. Croome KP, Mathur AK, Lee DD, Moss AA, Rosen CB, Heimbach JK, et al. Outcomes of Donation After Circulatory Death Liver Grafts From Donors 50 Years or Older: A Multicenter Analysis. Transplantation 2018;102:1108-14.

4. Pan $\mathrm{HC}$, Jenq $\mathrm{CC}$, Lee $\mathrm{WC}$, Tsai $\mathrm{MH}$, Fan $\mathrm{PC}$, Chang $\mathrm{CH}$, et al. Scoring systems for predicting mortality after liver transplantation. PLoS One 2014;9:e107138.

5. Ozier $Y$, Klinck JR. Anesthetic management of hepatic transplantation. Curr Opin Anaesthesiol 2008;21:391400

6. Bernal W, Wendon J.Acute liver failure. N Engl J Med 2013;369:2525-34.

7. Taşkıran $E$, Akar $H$, Yıldııı $M$, Erbaş O. Liver transplantation: indications, contraindications, rejection and longterm follow-up. FNG \& Bilim Tıp Transplantasyon Dergisi 2016;1:59-66.

8. Nandhakumar A, McCluskey SA, Srinivas C, Chandy TT. Liver transplantation: Advances and perioperative care. Indian J Anaesth 2012;56:326-35.

9. Kumar R, Shalimar, Sharma H, Goyal R, Kumar A, Khanal $S$, et al. Prospective derivation and validation of early dynamic model for predicting outcome in patients with acute liver failure. Gut 2012:61:1068-75

10. Feltracco P, Carollo C, Barbieri S, Pettenuzzo T, Ori C. Early respiratory complications after liver transplantation. World J Gastroenterol 2013;19:9271-81.

11. Cholongitas E, Betrosian A, Senzolo M, Shaw S, Patch D, Manousou P, et al. Prognostic models in cirrhotics admitted to intensive care units better predict outcome when assessed at $48 \mathrm{~h}$ after admission. J Gastroenterol Hepatol 2008;23:1223-7.

12. Akan M. Critical Care Management after Adult Liver Transplantation. J Turk Soc Intens Care 2017;15:1-20.

13. Karvellas CJ, Subramanian RM. Current Evidence for Extracorporeal Liver Support Systems in Acute Liver Failure and Acute-on-Chronic Liver Failure. Crit Care Clin 2016;32:439-51.
14. Liu H, Lee SS. Predicting cardiovascular complications after liver transplantation: 007 to the rescue? Liver Transpl 2011:17:7-9.

15. Liu H, Jayakumar S, Traboulsi M, Lee SS. Cirrhotic cardiomyopathy: Implications for liver transplantation. Liver Transpl 2017;23:826-35.

16. Fede G, Privitera G, Tomaselli T, Spadaro L, Purrello F. Cardiovascular dysfunction in patients with liver cirrhosis. Ann Gastroenterol 2015;28:31-40.

17. Møller S, Henriksen JH. Cirrhotic cardiomyopathy. J Hepatol 2010;53:17990.

18. Møller S, Henriksen JH. Cardiovascular complications of cirrhosis. Gut 2008:57:268-78.

19. Licata A, Mazzola A, Ingrassia D, Calvaruso V, Cammà $\mathrm{C}$, Craxì A. Clinical implications of the hyperdynamic syndrome in cirrhosis. Eur J Intern Med 2014:25:795-802

20. Møller S, Bendtsen F. The pathophysiology of arterial vasodilatation and hyperdynamic circulation in cirrhosis. Liver Int 2018;38:570-80.

21. Rodríguez-Roisin R, Krowka MJ. Hepatopulmonary syndrome--a liverinduced lung vascular disorder. N Engl J Med 2008;358:2378-87.

22. Bağlar E, Türkay C. Hepatopulmoner Sendrom. Güncel Gastroenteroloji 2012;16:147-55.

23. Alataş Alkım C. Portopulmonary Hypertension. The Medical Bulletin of Şişli Etfal Hospital 2014;48:257-63.

24. Sussman N, Kaza V, Barshes N, Stribling R, Goss J, O'Mahony C, et al. Successful liver transplantation following medical management of portopulmonary hypertension: a single-center series. Am J Transplant 2006;6:2177-82.

25. Ashfaq M, Chinnakotla S, Rogers L, Ausloos K, Saadeh S, Klintmalm $\mathrm{GB}$, et al. The impact of treatment of portopulmonary hypertension on survival following liver transplantation. Am J Transplant 2007;7:1258-64.

26. European Association for the Study of the Liver. EASL clinical practice guidelines on the management of ascites, spontaneous bacterial peritonitis, and hepatorenal syndrome in cirrhosis. $J$ Hepatol 2010;53:397-417.

27. Salerno $F$, Gerbes $A$, Ginès $P$, Wong $F$, Arroyo $V$. Diagnosis, prevention and treatment of hepatorenal syndrome in cirrhosis. Gut 2007:56:1310-8.

28. Madonia S, D'Amico G, Traina M, Gatto G, Virdone R, Salamone N, et al. Prognostic indicators of successful endoscopic sclerotherapy for prevention of rebleeding from oesophageal varices in cirrhosis: a long-term cohort study. Dig Liver Dis 2000;32:782-91.

29. Saner FH, Gieseler RK, Akız H, Canbay A, Görlinger K. Delicate balance of bleeding and thrombosis in end-stage liver disease and liver transplantation. Digestion 2013;88:135-44.

30. Blasi A. Coagulopathy in liver disease: Lack of an assessment tool. World J Gastroenterol 2015;21:10062-71.

31. Eilers $\mathrm{H}$. Advances in anesthesia and critical care. Liver Transpl 2016;22:20-24.

32. Hevesi ZG, Lopukhin SY, Mezrich JD, Andrei AC, Lee M. Designated liver transplant anesthesia team reduces blood transfusion, need for mechanical ventilation, and duration of intensive care. Liver Transpl 2009;15:460-5.

33. Reich DL, Wood RK Jr, Emre S, Bodian CA, Hossain S, Krol M, et al. Association of intraoperative hypotension and pulmonary hypertension with adverse outcomes after orthotopic liver transplantation. J Cardiothorac Vasc Anesth 2003:17:699-702.

34. Xu ZD, Xu HT, Yuan HB, Zhang $H$, Ji RH, Zou Z, et al. Postreperfusion syndrome during orthotopic liver transplantation: a single-center experience. Hepatobiliary Pancreat Dis Int 2012;11:34-9.

35. Bukowicka B, Akar RA, Olszewska A Smoter P, Krawczyk M. The occurrence of postreperfusion syndrome in orthotopic liver transplantation and its significance in terms of complications and short-term survival. Ann Transplant 2011;16:26-30.

36. Aufhauser DD Jr, Rose T, Levine M, Barnett R, Ochroch EA, Aukburg $\mathrm{S}$, et al. Cardiac arrest associated with reperfusion of the liver during transplantation: incidence and proposal for a management algorithm. Clin Transplant 2013;27:185-92.

37. Levy B, Fritz C, Tahon E, Jacquot A, Auchet T, Kimmoun A. Vasoplegia treatments: the past, the present, and the future. Crit Care 2018;22:52.

38. Russell JA, Walley KR, Singer J, Gordon AC, Hébert PC, Cooper DJ, et al. Vasopressin versus norepinephrine infusion in patients with septic shock. N Engl J Med 2008;358:877-87.

39. Hajiar LA, Vincent JL, Barbosa Gomes Galas FR, Rhodes A, Landoni G, Osawa EA, et al. Vasopressin versus Norepinephrine in Patients with Vasoplegic Shock after Cardiac Surgery: The VANCS Randomized Controlled Trial. Anesthesiology 2017;126:85-93. 
40. Valentine $E$, Gregorits $M$, Gutsche JT, Al-Ghofaily L, Augoustides JG. Clinical update in liver transplantation. J Cardiothorac Vasc Anesth 2013;27:80915.

41. Dec GW, Kondo $N$, Farrell $M L$, Dienstag J, Cosimi AB, Semigran MJ. Cardiovascular complications following liver transplantation. Clin Transplant 1995:9:463-71.

42. Therapondos G, Flapan AD, Plevris JN, Hayes PC. Cardiac morbidity and mortality related to orthotopic liver transplantation. Liver Transpl 2004:10:1441-53.

43. Fouad TR, Abdel-Razek WM, Burak KW, Bain VG, Lee SS. Prediction of cardiac complications after liver transplantation. Transplantation 2009;87:763-70.

44. Siesjö BK. Pathophysiology and treatment of focal cerebral ischemia. Part I: Pathophysiology. J Neurosurg. 1992:77:169-84.

45. Xia VW, Worapot A, Huang S, Dhillon A, Gudzenko V, Backon A, et al. Postoperative atrial fibrillation in liver transplantation. Am J Transplant 2015;15:687-94.

46. Reydellet L, Blasco V, Mercier MF, Antonini F, Nafati C, Harti-Souab K, et al. Impact of a goal-directed therapy protocol on postoperative fluid balance in patients undergoing liver transplantation: a retrospective study. Ann Fr Anesth Reanim 2014;33:e47-54.

47. Schortgen F, Girou E, Deye N, Brochard L; CRYCO Study Group. The risk associated with hyperoncotic colloids in patients with shock. Intensive Care Med 2008;34:2157-68.

48. Demetris A, Adams D, Bellamy C, Blakolmer K, Clouston A, Dhillon AP, et al. Update of the International Banff Schema for Liver Allograft Rejection: working recommendations for the histopathologic staging and reporting of chronic rejection. An International Panel. Hepatology 2000;31:792-9.

49. Snowden $\mathrm{CP}$, Hughes $\mathrm{T}$, Rose J, Roberts DR. Pulmonary edema in patients after liver transplantation. Liver Transpl 2000:6:466-70.

50. Aduen JF, Stapelfeldt WH, Johnson MM, Jolles HI, Grinton SF, Divertie GD, et al. Clinical relevance of time of onset, duration, and type of pulmonary edema after liver transplantation. Liver Transpl 2003:9:764-71.

51. O'Brien JD, Ettinger NA. Pulmonary complications of liver transplantation. Clin Chest Med 1996;17:99-114.

52. de Boer MT, Christensen MC, Asmussen $M$, van der Hilst CS, Hendriks HG, Slooff $M J$, et al. The impact of intraoperative transfusion of platelets and red blood cells on survival after liver transplantation. Anesth Analg 2008;106:32-44.

53. Saner FH, Olde Damink SW, Pavlakovic G, Sotiropoulos GC, Radtke A, Treckmann $J$, et al. How far can we go with positive end-expiratory pressure (PEEP) in liver transplant patients? J Clin Anesth 2010;22:104-9.

54. Paramesh AS, Roayaie $S$, Doan $Y$, Schwartz ME, Emre S, Fishbein T, et al.
Post-liver transplant acute renal failure: factors predicting development of endstage renal disease. Clin Transplant 2004;18:94-9.

55. de Haan JE, Hoorn EJ, de Geus $\mathrm{HRH}$. Acute kidney injury after liver transplantation: Recent insights and future perspectives. Best Pract Res Clin Gastroenterol 2017;31:161-9.

56. Myburgh JA, Finfer S, Bellomo R, Billot L, Cass A, Gattas D, et al. Hydroxyethyl starch or saline for fluid resuscitation in intensive care. N Engl J Med 2012;367:1901-11.

57. Nadeem A, Salahuddin N, El Hazmi A, Joseph M, Bohlega B, Sallam H, et al. Chloride-liberal fluids are associated with acute kidney injury after liver transplantation. Crit Care 2014;18:625.

58. Portal AJ, McPhail MJ, Bruce M, Coltart I, Slack A, Sherwood R, et al. Neutrophil gelatinase--associated lipocalin predicts acute kidney injury in patients undergoing liver transplantation. Liver Transpl 2010;16:1257-66.

59. Francoz C, Nadim MK, Durand F. Kidney biomarkers in cirrhosis. J Hepatol 2016;65:809-24.

60. Figueiredo $F$, Dickson ER, Pasha $T$, Kasparova P, Therneau T, Malinchoc M, et al. Impact of nutritional status on outcomes after liver transplantation. Transplantation 2000;70:1347-52.

61. Zivkovic SA. Neurologic complications after liver transplantation. World J Hepatol 2013;5:409-16. 